\title{
ASPEK PSIKOLOGI TOKOH UTAMA DALAM NOVEL SANG PEMIMPI KARYA ANDREA HIRATA
}

\author{
PSYCOLOGY ASPECT MAIN CHARACTER IN SANG PEMIMPI \\ NOVELS WORKTS ANDREA HIRATA
}

\author{
Agus Yulianto \\ Balai Bahasa Provinsi Kalimantan Selatan, Jalan A. Yani, Km 32,2 Loktabat, \\ Banjarbaru, Kalimantan Selatan \\ Telp: 0511-4772641, Pos-el: agusb.indo@gmail.com
}

\begin{abstract}
Abstrak
Tujuan penelitian ini adalah untuk mengetahui wujud konflik batin yang terjadi dalam diri tokoh utama dan pesan positif yang dikandungnya. Adapun masalah dalam penelitian ini adalah bagaimanakah wujud konflik batin yang terjadi dalam diri tokoh utama dan apa pesan positif yang dikandungnya. Kajian ini menggunakan metode deskriptif analitik. Berdasarkan hasil analisis dapat diketahui bahwa konflik batin yang menimpa tokoh utama merupakan media penyampaian pesan positif pengarang terhadap pembacanya. Hal itu terutama menyangkut konflik batin yang berkaitan dengan moral dan konflik batin yang menyangkut rasa pesimis terhadap keberhasilan dalam sebuah perjuangan yang seharusnya tidak perlu ada.
\end{abstract}

Kata kunci: Psikologi, tokoh, novel

\begin{abstract}
The purpose of this study is to understand the form of inner conflict in the main characters and positive messages the author shared. The problem of this research is how the form of inner conflict of the main character and what positive messages the author shared. This study uses analytical descriptive methodology. Based on the results of the analysis, it showed that the inner conflict of the main character is a medium of the writer to convey the author's positive messages to the readers. It is primarily concerned with the inner conflict of moral and pessimistic the main character feels for the success of a struggle that should not have existed.
\end{abstract}

Keywords: Psychology, character, novel

\section{Pendahuluan}

Karya sastra, khususnya novel, diciptakan pengarang untuk menyampaikan hal-hal yang dianggap positif kepada pembaca. Metode yang digunakan oleh pengarang untuk menyampaikan pesan positif tersebut dapat dilakukan dengan berbagai cara. Salah satunya adalah melalui konflik batin yang dialami oleh tokoh rekaannya.
Menurut Jahdiah (2013:143) sebagai seorang manusia yang hidup dan berinteraksi dengan sesamanya, pengarang dengan bermodalkan kepekaan jiwa senantiasa mencerap masalah kemanusiaan dan kehidupan melalui pengamatan dan penghayatannya. Kemampuan menangkap gejala-gejala kejiwaan baik dari dirinya sendiri maupun orang lain oleh pengarang kemudian diolah dan diendapkan serta 
diekspresikan dalam proses kreatif cipta sastra sehingga lahirlah karya sastra sebagai sebuah kontemplasi pengarang. Dengan demikian, pengalaman kejiwaan yang semula mengendap dalam jiwa pengarang telah beralih menjadi suatu master piece cipta sastra yang terproyeksikan lewat ciri-ciri kejiwaan para tokoh imejinernya. Tokoh dalam "dunia baru", dunia rekaan sang pengarang. Hal inilah yang menurut Roekhan (dalam Aminuddin, 1990:93) menyebabkan karya sastra atau teks sastra dapat didekati dengan menggunakan pendekatan psikologi.

Lebih jauh Jahdiah (2013:144) menyatakan karya sastra yang dipandang sebagai fenomena psikologis akan menampilkan aspek-aspek kejiwaan melalui tokoh-tokoh, melalui tuturan yang dihasilkan tokoh. Meskipun karya sastra bersifat kreatif dan imajiner, pencipta tetap sering memanfaatkan aspek psikologis untuk menghidupkan tokoh-tokoh cerita.

Aspek psikologis berupa konflik batin sang tokoh merupakan instrument yang kerap kali digunakan pengarang dalam menghidupkan dan bahkan menyampaikan pesan positif kepada pembacanya. Salah satu pengarang yang sangat piawai dalam memaksimalkan peran tokoh dalam menyampaikan pesan positif melalui konflik batin dalam cerita novel adalah Andrea Hirata. Andrea Hirata adalah seorang novelis yang sangat fenomenal saat ini. Novel-novel yang dihasilkannya selalu menjadi best seller di tengah masyarakat. Novel-novel yang dihasilkan Andrea Hirata tidak saja menampilkan tentang budaya masyarakat tertentu, juga terkadang semangat tekad yang dimiliki sang tokoh yang sangat inspiiratif.

Salah satu novel Andrea Hirata yang sangat fenomenal adalah novel yang berjudul Sang Pemimpi. Kekuatan dalam novel ini salah satunya adalah mengenai kekuatan tekad sang tokoh dalam mengejar impian hidupnya. Haikal sebagai tokoh utama dalam novel ini adalah anak seorang dari keluarga miskin yang tinggal di Pulau Belitung yang memiliki cita-cita untuk dapat belajar di Universitas Sorbone, Perancis. Cita-cita tersebut terasa muskil untuk dapat terjadi. Hal itu disebabkan jangankan untuk sampai kuliah di Perancis, untuk menyambung hidup sehari-hari saja sang tokoh sudah harus jungkir balik mencari makan. Dalam pengejaran untuk menggapai cita-cita itulah banyak terjadi konflik batin dalam diri sang tokoh sendiri seperti antara keputusasaan dengan keyakinan atau antara godaan dengan keyakinan. Hal ini merupakan unsur yang sangat menarik untuk dinalisis dalam mengupas novel Sang Pemimpi karya Andrea Hirata ini.

Novel ini memang sangat inspiratif terutama bagi orang-orang yang memiliki latar belakang ekonomi sejenis dalam menggapai cita-cita hidup atau mengubah hidupnya menjadi lebih baik. Dengan demikian, tujuan penelitian ini adalah untuk mengetahui wujud konflik batin yang terjadi dalam diri tokoh utama dan pesan positif yang dikandungnya. Adapun masalah dalam penelitian ini adalah bagaimanakah wujud konflik batin yang terjadi dalam diri tokoh utama dan apa pesan positif yang dikandungnya.

\section{Teori dan Metode \\ 2.1 Kajian Teori}

Menurut Aminuddin (2004:79) peristiwa dalam karya fiksi seperti halnya peristiwa dalam kehidupan sehari-hari, selalu diemban oleh tokoh atau pelakupelakunya, pelaku yang mengemban peristiwa dalam cerita fiksi sehingga terjalin suatu cerita disebut penokohan. Sementara itu, menurut Nurgiyantoro (2010:79) penokohan adalah pelukisan gambaran yang jelas tentang seorang yang ditampilkan dalam sebuah cerita. 
Nurgiyantoro (2010:177) kemudian membagi kriteria tokoh menjadi beberapa bagian, yaitu adanya tokoh utama dan tokoh tambahan. Tokoh utama adalah tokoh yang diutamakan penceritaannya dalam novel yang bersangkutan, ia merupakan tokoh yang paling banyak diceritakan, baik sebagai pelaku kejadian maupun yang dikenai kejadian.

Menurut Semi (2012:67) psikologi sastra adalah suatu disiplin ilmu yang mengkaji kandungan suatu karya sastra yang memuat peristiwa kehidupan manusia diperankan oleh tokoh-tokoh yang imajiner yang ada di dalam atau mungkin diperankan oleh tokoh-tokoh faktual. Hal tersebut merangsang pembaca untuk mengetahui lebih jauh tentang seluk beluk manusia yang beraneka ragam.

Menurut Endraswara (2013:96) psikologi sastra adalah kajian sastra yang memandang karya sastra sebagai aktivitas kejiwaan. Pengarang akan menggunakan cipta, rasa, dan karsa berkarya. Begitu pula pembaca dalam menanggapi karya juga tidak lepas kejiwaan masing-masing. Bahkan sebagaimana sosiologi, refleksi psikologi sastra pun mengenal karya sastra sebagai pantulan kejiwaan. Pengarang akan menangkap gejala kejiwaan kemudian di olah ke dalam teks dan dilengkapi dengan kejiwaannya.

Menurut Jahdiah (2013:148) psikologi sastra merupakan gabungan dari teori psikologi dengan teori sastra. Sastra sebagai "gejala kejiwaan" di dalamnya terkandung fenomenafenomena kejiwaan yang nampak lewat perilaku tokoh-tokohnya, sehingga karya teks sastra dapat dianalisis dengan menggunakan pendekatan psikologi. Menurut Jatman (dalam Endraswara, 2013: 98) karya sastra dan psikologi memang memiliki pertautan yang erat karena baik sastra maupun psikologi memiliki objek yang sama, yaitu kehidupan manusia. Psikologi dan sastra memiliki hubungan fungsional karena sama-sama untuk mempelajari keadaan kejiwaan orang lain, bedanya dalam psikologi gejala tersebut riil sedangkan dalam sastra bersifat imajinatif.
Menurut
Roekhan
(dalam

Aminuddin, 1990:94) karya sastra yang dapat dijadikan bahan kajian melalui pendekatan secara psikologis adalah karya-karya sastra yang mengembangkan kejiwaan tokoh-tokohnya, yakni karya prosa dan drama. Lebih jauh ditandaskan bahwa pendekatan tekstual dalam psikologi sastra yang bertumpu pada pendekatan psikologi (dalam pendekatan ekspresif dan pendakatan pragmatis) kemudian berkembang melalui pendekatan-pendekatan psikologi yang lain seperti pendekatan kognitif, behavioral, gahnzeid, dan pendekatan eksistensial.

Lebih jauh menurut Roekhan (dalam Endraswara, 2013:97-98) menyatakan psikologi sastra ditopang oleh tiga pendekatan sekaligus. Pertama, pendekatan tekstual yang mengkaji aspek psikologis tokoh dalam karya sastra. Kedua, pendekatan reseptif-pragmatik yang mengkaji aspek psikologi pembaca sebagai penikmat karya sastra. Ketiga, pendekatan ekspresif yang mengkaji aspek psikologis sang penulis ketika melakukan proses kreatif yang terproyeksi lewat karyanya, baik penulis sebagai pribadi maupun wakil masyarakat.

Pendekatan tekstual yang mengkaji aspek psikologis tokoh dalam karya sastra biasanya terjabarkan dalam wujud konflik batin sang tokoh itu sendiri. Menurut Indrawati (2014:24) konflik adalah percekcokan, perselisihan atau pertentangan. Dalam sastra, konflik diartikan sebagai ketegangan atau pertentangan di dalam cerita rekaan atau drama, yakni pertentangan antara dua kekuatan, pertentangan dalam diri satu tokoh, pertentangan antara dua tokoh, 
dan sebagainya. Menurut Kamus Besar Bahasa Indonesia Edisi V (2016:587) konflik batin adalah konflik yang disebabkan oleh adanya dua gagasan atau lebih, atau keinginan yang saling bertentangan untuk menguasai diri sehingga memengaruhi tingkah laku. Selain itu menurut Nurgiyantoro (2010: 125) konflik batin adalah konflik yang terjadi di dalam hati, jiwa seorang tokoh atau tokoh-tokoh cerita. Jadi, konflik batin merupakan konflik yang dialami manusia dengan dirinya sendiri atau permasalahan intern seorang manusia, misalnya hal tersebut terjadi karena akibat adanya pertentangan antara dua keinginan, keyakinan, pilahan yang berbeda, harapan-harapan atau masalahmasalah lainnya. Tingkat kompleksitas konflik yang ditampilkan dalam sebuah karya fiksi dalam hal banyak hal, menentukan kualitas, intensitas, dan ketertarikan karya tersebut.

Menurut Stanton

(dalam Nurgiyantoro, 2010:124) menyatakan bahwa konflik secara bentuk kejadiannya dibedakan ke dalam dua kategori, yaitu konflik internal dan konflik eksternal. Konflik internal adalah konflik yang terjadi di dalam hati, jiwa seorang tokoh (atau tokoh-tokoh cerita). Jadi konflik tersebut merupakan konflik yang dialami manusia dengan dirinya sendiri dan lebih merupakan permasalahan intern seorang manusia. Konflik eksternal adalah konflik yang terjadi antara seorang tokoh dengan sesuatu di luar dirinya, mungkin dengan alam atau mungkin dengan lingkungan manusia.

Pesan positif yang terdapat dalam sebuah karya sastra dapat juga dinamakan dengan amanat cerita. Menurut Sudjiman (1988:58) amanat adalah ajaran moral atau pesan yang ingin disampaikan dalam sebuah karya sastra. Amanat yang terdapat dalam sebuah karya sastra dapat secara implisit atau eksplisit. Secara implisit, bila pesan atau ajaran moral itu disiratkan dalam perlakuan tokoh baik berupa konflik batin atau tingkah laku pada umumnya. Secara eksplisit bila pengarang pada tengah atau akhir cerita menyampaikan seruan, nasihaat, anjuran, larangan, dan sebagainya berkenaan dengan gagasan yang mendasari cerita itu.

\subsection{Metode Penelitian}

Metode yang digunakan dalam penelitian ini adalah metode deskriptif analitik. Menurut Ratna (2011:53) metode deskriptif analitik dilakukan dengan cara mendeskripsikan fakta-fakta selanjutnya dianalisis. Adapun teknik penelitian menggunakan teknik studi pustaka.

Data penelitian berupa konflik batin sang tokoh utama yang terdapat dalam paragraf-paragraf yang menjadi objek penelitian. Data penelitian kemudian dianalisis. Analisis data sifatnya menuturkan, memaparkan, dan menafsirkan. Pendekatan yang digunakan dalam analisis data adalah pendekatan psikologi sastra. Dengan pendektan sosiologi sastra diuraikan konflik batin tokoh utama yang terdapat didalam novel.

\section{Pembahasan}

\subsection{Sinopsis Cerita}

Novel ini bercerita tentang masa SMA tiga orang pemuda, yaitu Ikal, Arai dan Jimbron. Mereka bertiga adalah remaja yang berasal dari Belitong dan melanjutkan sekolah di Manggar, SMA Negeri pertama di Manggar. Untuk mencukupi kebutuhan sekolahnya Arai, Ikal dan Jimbron bekerja paruh waktu sebagai kuli di pasar ikan. Arai adalah yang paling cerdas di antara mereka bertiga, selalu mengutip kata-kata inspiratif dari berbagai sumber "tak semua yang dihitung bisa diperhitungkan dan tak semua yang diperhitungkan bisa di hitung", sedangkan Ikal yang sangat mengidolakan H. Roma Irama akan 
mengutip kalimat dari lirik lagu raja dagdut tersebut "Darah muda adalah darahnya para Remaja" sedangkan Jibron yang sangat menyukai kuda akan mengeluarkan kalimat yang tidak jauhjauh dari bahasan tentang kuda.

Kehidupan SMA adalah perjalanan mencari jati diri. Arai, saat itu jatuh cinta pada teman sekelasnya, Zakia Nurmala, sedangkan Ikal jatuh cinta pada putri seorang Cina, A Ling, dan Jimbron jatuh cinta pada Kuda. Arai yang paling giat mendekati cintanya, dia bahakan belajar bernyanyi dan bermain gitar hanya untuk menggoda Zakiah Nurmalanya.

Ahirnya mereka tamat SMA, Ikal yang terpengaruh dengan mimpinya Arai untuk menuju ke Paris dan mengelilingi dunia, tidak mau hanya putus sampai di SMA, maka dia dan Arai menggunakan uang tabungan mereka selama ini untuk berangkat ke Jakarta. Ikal diterima di UI jurusan Ekonomi. Dia menjalani masa kuliah yang cukup sulit yaitu kuliah sambil kerja, namun ahirnya dia bisa lulus tepat pada waktunya. Namun mimpi mereka tak hanya sampai disitu. Paris yang menjadi impian mereka belum tercapai, maka Arai dan Ikal berusaha mendapatkan beasiswa agar bisa melanjutkan kuliah di Paris.

Arai tiba-tiba menghilang, Ikal yang kini sendiri, kerja serabutan untuk bertahan hidup, berahir di kantor pos. mimpinya untuk ke Paris sudah hilang bersamaan dengan kepergian Arai yang entah kemana. Proposal beasiswa untuk ke Paris tak di gubrisnya lagi.

Beberapa bulan kemudian, Ikal memutuskan untuk mengajukan proposal beasiswa tersebut, meski tanpa Arai. Tak di sangka, Ikal kembali bertemu dengan Arai di kantor Pengajuan beasiswa. Mereka berdua berpelukan dan berjanji akan bersama-sama ke Paris. Ternyata mimpi untuk ke Paris telah mempertemukan mereka kembali.

\subsection{Konflik Batin Tokoh Utama dalam Novel Sang Pemimpi \\ 3.2.1 Konflik Batin yang Berkaitan dengan Moralitas}

Tokoh utama dalam novel ini adalah seorang anak yang bernama Haikal atau yang biasa disebut Ikal. Haikal sendiri merupakan anak Melayu Belitong yang lahir dari keluarga yang boleh dikatakan kurang mampu. Ayah Haikal hanya seorang buruh kasar dipertambangan Timah di Belitong. Hidup keluarga Haikal sangat sederhana. Akan tetapi, bukan berarti ayah Haikal tidak memperdulikan pendidikan bagi anaknya, terutama bagi Haikal.

Setelah menyelesaikan pendidikan sekolah pertamanya, Haikal melanjutkan pendidikan SMA Negeri di Manggar. Haikal beserta Arai dan Jimbron mengontrak di sebuah kontrakan sederhana. Untuk menutupi kebutuhan sehari-hari, Haikal dan Arai bekerja sebagai kuli panggul di pasar ikan. Kehidupan tersebut mereka jalani secara biasa dari hari ke hari.

Pada suatu hari terpasang sebuah poster di bioskop yang terletak tidak jauh dari rumah kontrakan Haikal. Poster tersebut menampilkan sebuah gambar wanita yang sangat tidak sopan. Hal itu disebabkan wanita yang dipajang dalam poster tersebut menampilkan wanita muda yang memakai busana sangat minim sehingga memancing nafsu para lelaki yang memandangnya. Hal itu terlihat dalam kutipan berikut.

"Di sana, ya, di sana, hanya ada carik kecil berwarna merah. Bukaan terpal naik lagi, dan dadanya juga hanya dililit carik merah berupa tali-temali. Aku terbelalak. Jimbron menggenggam lengan Arai kuat-kuat, lalu menggigitnya. Arai sudah tak bisa merasakan sakit. Mati rasa. Mulutnya seperti anjing melihat tulang. Aku, cdpat-cepat menutup mataku dengan kedua tangan. Tapi aneh, jari-jariku bergeser sendiri dengan tenaga yang tak 
dapat kutandingi. Sungguh bergeser sendiri tak terkendali! Kututup lagi mukaku. Kuingatkan diriku sendiri bahwa aku berijazah Sekolah Dasar Laskar Pelangi Muhammadiyaah, kawah candradimuka pendadaran Islam yang tangguh. Kututup kembali jariku, tapi jari-jari itu kembali melawan tuannya. Aku malu dan merasa sangat bersalah kepada Buya Kiai Haji Achmad Dahlan, pendiri Muhammadiyah (Hirata: 88).

Efek yang ditimbulkan dari keberadaan poster film tersebut menimbulkan konflik batin dalam diri Haikal. Konflik batin itu berupa pertarungan antara moralitas dengan nafsu syawat yang merupakan naluri purba manusia. Haikal adalah salah satu siswa terbaik di SMAN Manggar. Dia juga merupakan alumni dari sekolah dasar yang berbasis agama, yaitu Muhammadiyah. Ajaran-ajaran agama sesungguhnya telah tertanam dalam dirinya. Etika, norma, kesantunan sebagai bagian pembentukan moral sesungguhnya telah terbentuk dalam dirinya. Akan tetapi, pada saat usia muda yang masih penuh dengan gejolak, sebuah godaan yang sangat tidak terduga menimpa dirinya. Sebuah korporasi kapitalis yang tidak memperhatikan moralitas, etika dan norma dan yang hanya mementingkan keuntungan semata atas nama kebebasan berekspresi telah menghadirkan sebuah film yang sangat vulgar untuk ukuran bangsa Indonesia. Film tersebut menyuguhkan tontonan yang mengumbar aurat tentang perkosaan seorang pembantu oleh majikannya.

Pada titik ini konflik batin yang menimpa Haikal adalah antara keinginan untuk menonton film tersebut atau tidak. Poster perempuan yang mengudang hawa nafsu tersebut berhari-hari menebar teror terhadap moralitas Haikal. Bayangan cabul yang terimajinasi berkat poster film itu menimbulkan asosiasi dan fantasi seks yang luar biasa terhadap diri Haikal termasuk Arai dan Jimbron teman satu kontarakannya. Puncak dari fantasi itu adalah seakan-akan wanita dalam poster menjadi hidup dan merayu mereka untuk datang kedalam gedung bioskop untuk menonton film yang tidak senonoh tersebut. Hal itu terlihat dalam kutipan berikut.

"Lalu, suatu pagi buta, sebelum subuh, kelelahan setelah pontangpanting memikul ikan. Kami duduk bertiga,, nanar mengamati inci demi inci lekukan maut wanita itu yang makin membius disirami cahaya lampu neon. Kami diam melamun dengan pikiran masing-masing. Pikiran yang semburat menerobos pelosok-pelosok gelap tak bermoral. Lalu perlahan-lahan senyum genit wanita diposter itu merekah. Dia hidup! Berbicara kepada kami, lembut sekali bak busa-busa sabun. "Hai.....di sana! Aiiih....,siapa namau? Ah, sudahlah, tak penting! Tapi, tak tahukah hidup hanya sekali? Oh, lihatlah dirimu: muda, tampan, tersia-sia...." Kami melongo. "Kau habiskan waktu mudamu hanya untuk membanting tulang? Aiiih...., mengapa keras sekali pada dirimu sendiri? Yuk, lupakan sejenak kesusahan. Dua ratus tahun lagi keadaan akan sama saja! Ayo, ayolah, temui aku di dalam. Kutunggu, ya! (Hirata: 90).

Rupanya konflik batin yang timbul dalam diri Haikal akibat poster film yang tidak senonoh tersebut dimenangkan oleh hawa nafsunya. Haikal bersama Arai dan Jimbron akhirnya mencoba mencari cara untuk dapat masuk ke gedung bioskop demi menonton film tersebut. Tidak mudah untuk masuk ke dalam gedung bioskop. Hal itu disebabkan terdapat peraturan yang melarang anak-anak pelajar untuk menonton di gedung bioskop. Akan tetapi, sebuah kejahatan moral terkadang selalu mempunyai cara untuk memenuhi hasratnya. Dengan meniru kebiasaan orang-orang Sawang, 
yaitu menutupi kepala dengan sarung, Haikal dan kawan-kawannya akhirnya dapat masuk ke gedung bioskop. Mereka menonton film tersebut dengan kemenangan penjajahan nafsu atas moral agama mereka dan moral akademik mereka.

Kemenangan nafsu atas moralitas mereka ternyata tidak berlangsung lama. Pak Mustar, guru di SMA Haikal memergoki kejahatan moral tersebut dan menyuruh Haikal serta Arai dan Jimbron untuk keluar dari gedung bioskop. Hal itu terlihat dalam kutipan berikut.

"Seisi gedung bioskop terhenyak membisu. Jangankan kami, bahkan seluruh penonton tak berkutik dibuatnya. Dia memang disegani siapa saja. "Ini rupanya pekerjaan kalian! Tak malu! Kalian sebut diri pelajar??! Pelajar macam apa kalian?!" Kami seperti maling tertangkap basahyang membongkar kandang ayam. Semua mata terhujam kepada kami. Kami menunduk karena takut dan malu tak tertanggungkan. Teriakan Pak Mustar tambah kencang, "Merendahkan diri sendiri! Itulah kerjaan kalian! Merendahkan diri sendiri!" Pak Mustar merampas sarung kami. "Lihatlah mukanya baik-baik, Saudara-saudara! Beginilah anak-anak Melayu sekarang!" Martabat kami diobral Pak Mustar habis-habisan. Para pengunjung bioskop mengangguk-angguk. "Keluar.....!" (Hirata:103).

\subsubsection{Konflik Batin yang Berkaitan dengan Motivasi}

Haikal adalah anak dari seorang buruh miskin dari pekerja pertambangan timah di Belitong. Walaupun miskin, Haikal mempunyai semangat atau motivasi yang tinggi untuk bersekolah. Haikal memiliki kecintaan yang luar biasa terhadap tradisi bersekolah. Oleh sebab itu, tidak heran bila kesusahan dalam menempuh pendidikan itu sama sekali tidak dihiraukannya. Kemiskinan yang merajut hari-harinya, tidak membuat Haikal putus harapan.

Setelah selesai menempuh pendidikan sekolah menengah pertama, Haikal melanjutkan bersekolah di SMAN Manggar. Haikal adalah anak yang pintar. Oleh sebab itu, tidak heran bila Haikal menempati urutan atau juara kelima di kelasnya. Untuk memenuhi kebutuhan hidupnya, Haikal bekerja sebagai kuli pengangkut ikan di pelabuhan yang dilakoninya pada pukul tiga pagi. Pekerjaaan itu dijalaninya tanpa ada keluhan sama sekali.

Motivasi bersekolah yang dimiliki Haikal semakin menguat setelah dia mendengarkan kalimat-kalimat inspiratif yang disampaikan oleh kepala sekolah sekaligus guru sastranya yang bernama Drs. Julian Ichsan Balia. Beliau menginspirasi murid-muridnya dengan pemahaman bahwa hidup ini sangat kompleks dan tidak ada peristiwa yang kebetulan. Seluruh peristiwa dalam hidup seorang manusia laksana mozaik yang terserak yang pada akhirnya akan membentuk manusia itu secara keseluruhan. Beliau mengajarkan kepada anak-anak muridnya untuk mengejar ilmu kemana saja. Beliau juga mengajarkan kepada anak-anak muridnya untuk mengejar ilmu kemana saja. Hal itu terlihat dalam kutipan berikut.

"Jelajahi kemegahan Eropa sampai Afrika. Temukan berliannya budaya sampai ke Prancis. Langkahkan kakimu di atas altar suci almamater terhebat tiada tara: Sorbonne. Ikuti jejak-jejak Sartre, Louis Pateur, Montesquieu, Voltaire. Di sanalah orang belajar Science, sastra, dan seni hingga mengubah dunia" (Hirata:61).

Motivasi yang disampaikan oleh pak Balia tersebut secara tidak sadari telah membentuk tekad yang kuat dalam diri Haikal untuk suatu saat nanti akan bersekolah sampai ke Prancis. Hal itu sangat berbanding terbalik dengan 
kondisi atau realita kehidupan Haikal sendiri. Jangankan untuk bersekolah sampai ke Eropa yang memerlukan biaya tidak sedikit, untuk mencukupi kehidupan sehari-hari saja sudah susah. Oleh sebab itu, tidak heran bila Haikal dapat terkategorikan sebagai seorang "pemimpi".

Impian dan realitas kehidupan yang dijalani oleh Haikal pada suatu saat mencapai titik nadir. Realitas kehidupan yang sulit secara ekonomi yang dijalani oleh Haikal lambat laun menciptakan beban psikologis atau konflik batin untuk jangan terlalu muluk untuk bermimpi dan mencoba untuk mau menerima keadaan apa adanya. Apalagi kegagalankegagalan pendidikan yang dialami oleh sahabat-sahabatnya, membuat Haikal dipaksa untuk menerima realitas seperti apa adanya. Konflik batin itu terlihat dalam kutipan berikut.

"Satu lapisan tipis tersingkap, membuka mataku bahwa hidup yang terbentang di depanku akan semakin tak mudah. Aku, Jimbron, dan Arai yang kusaksikan bekerja di restoran Tionghoa, menjadi kernet, dan pedagang kweni dari pulau itu adalah manifestasi dari bagaimana aku melihat kemungkinankemungkinan dalam hidupku. Aku sadar, setelah menamatkan SMA, nasibku akan sama saja dengan nasib kedua sahabatku waktu SMP: Lintang dan Mahar.

Berada dalam pergaulan remaja Melayu yang seharian membanting tulang, mendengar pandangan mereka tentang masa depan, dan melihat bagaimana mereka satu persatu berakhir, lambat laun memengaruhiku untuk menilai situasiku secara realistis. Namun, tak pernah kusadari bahwa sikap realistis itu sesungguhnya mengandung bahaya sebab ia memiliki hubungan dekat dengan rasa pesimis. Realitas tak lain adalah pedal rem yang sering menghambat harapan seorang.

Sekarang, setap kali Pak Balia membuai kami dengan puisi-puisi indah Prancis, aku hanya menunduk, menghitung hari yang tersisa untuk memikul ikan dan menabung. Pulang ke kamar kontrakan, aku melongok ke dalam kaleng celenganku yang penuh, penuh uang receh. Darah mudaku yang berapiapi mulai padam.

Aku sangat mafhum bahwa tabunganku itu tak akan pernah mampu membawaku keluar dari pulau kecil belitong yang bau karat ini. Bagi kami, harapan sekolah ke Prancis tak ubahnya pungguk merindukan dipeluk purnama (Hirata: 132-133).

Efek dari pergolakan atau konflik batin yang menimpa Haikal ini adalah prestasi belajarnya yang menurun. Hal itu disebabkan, Haikal menjadi malas belajar karena diterjang oleh rasa pesimis yang menderanya. Akibatnya, Haikal menempati kursi urutan ke tujuh puluh lima saat pengambilan rapot. Hal itu berarti Haikal menempati rangking ke tujuh puluh lima di sekolahnya turun dari posisi awal yang menempati rangking kelima. Hal itu menyebabkan Arai dan guru-gurunya kecewa, terutama Pak Mustar. Secara tidak langsung Haikal telah menciptakan konflik tersendiri dengan Pak Mustar dan Arai. Pak Mustar adalah guru yang sangat menyesali keadaan yang menimpa Haikal. Hal itu disebabkan, Pak Mustar amat menghargai anak-anak Melayu yang dapat bersekolah di SMAN Manggar. Beliau beranggapan anak-anak yang bersekolah di SMAN Manggar adalah anak-anak pilihan dan pintar. Bahkan, anaknya sendiri pun tidak dapat bersekolah di SMAN Manggar karena tidak mencukupi nilai NEM-nya 
untuk dapat masuk di SMAN Manggar. Hal itu terlihat dalam kutipan berikut.

"Tujuh puluh lima! Tujuh puluh lima! Itulah nomor kursi ayahmu sekarang!" Aku dipanggil Pak Mustar, disemprotnyahabis-habisan, "Hanya tinggal satu semester tamat SMA, memalukan! Memalukan bukan buatan!" Aku terpana. "Keterlaluan! Orang sepertimu patut dibuat sekandang dengan Malin Kundang! Anak durhaka! Itulah orang sepertimu kalau kau ingin tahu! Sangkamu kau siapa? Kau pikir bisa menjaga kursimu dengan belajar sekehendak hatimu?" Suara Pak Mustar berat penuh sesal. Dia memang garang, tapi semua orang tahu bahwa sesungguhnya dia penuh perhatian. "Kini kau terdepak jauh dari garda depan itu." Dia menatapku geram. Dia memandang jauh keluar jendela. Lalu, dia berbalik. Suaranya tertahan. "Tahukah kau, Bujang? Sepanjang waktu aku bermimpi anakku duduk di kursi garda depan itu!" Aku terharu melihat mata Pak Mustar berkaca-kaca. "Kini, dia sekolah di Tanjong Pandan, di SMA yang monyet pun jika mendaftar akan diterima! Dan, kau, kausia-siakan kehormatan itu. Mengapa kau berhenti bercita-cita, Bujang? Pahamkah engkau, berhenti bercitacita adalah tragedi terbesar dalam hidup manusia!" (Hirata:137).

Tidak hanya dengan Pak Mustar konflik terjadi. Dengan Arai pun akhirnya Haikal mengalami konflik atas sikap pesimis yang menimpanya itu. Arai sangat marah terhadap Haikal karena telah mempersembahkan kursi urutan ke tujuh puluh lima kepada ayahnya dan itu menurut Arai sangat mempermalukan ayahnya Haikal yang sekaligus paman Arai sendiri.
"Seperti kebiasaannya, sebelum pulang, Ayah menepuk-nepuk lembut pundak kami dan mengucapkan sepatah kata salam dengan pelan. Aku tersedu sedan melihat Ayah menaiki sepedanya dan tertatih-tatih mengayuhnya meninggalkanku. Dadaku ingin meledak memandangi punggung ayahku yang perlahan-lahan meninggalkan meninggalkan halaman sekolah. "Puaskah kau sekarang?" Arai menumpahkan marah kepadaku. Aku membelakangi Arai karena aku ttak ingin dia melihat wajahku basah oleh air mata. "Apa yang terjadi denganmu, Ikal? Mengapa jadi begini sekolahmu? Kemana semangatmu itu? Mimpi-mimpi itu?" (Hirata:142).

Arai mencoba untuk mengembalikan kembali semangat dan tekad baja Haikal dalam menempuh jalur pendidikan. Arai mengatakan kepada Haikal bahwa bagi orang-orang miskin seperti mereka untuk mengubah nasib yang mereka punyai hanyalah semangat dan mimpi-mimpi belaka. Tanpa mimpi, orang-orang miskin seperti mereka menurut Arai akan mati dengan sendirinya. Arai mengingatkan kepada Haikal bahwa boleh jadi mereka akan tetap terpuruk dalam lingkaran kemiskinan seperti yang selama ini mereka jalani. Akan tetapi, menurut Arai jangan sekali-kali manusia mendahului nasib, yaitu menganggap hasil perjuangan melalui pendidikan tidak akan berhasil dan berakhir seperti sedia kala. Padahal nasib manusia ke depannya tidak ada yang tahu kecuali Tuhan.

"Mungkin, setelah tamat SMS, kita hanya akan mendulang timah atau menjadi kuli. Tapi di sini, Ikal, di sekolah ini, kita tak akan pernah mendahului nasib kita!" Mendahului nasib! Dua kata yang menjawab 
kekeliruanku melihat arah hidupku.

Pesimistis tak lebih dari sikap takabur mendahului nasib. "Kita lakukan yang terbaik di sini! Kita akan berkelana, kita akan menjelajah Eropa sampai ke Afrika! Kita akan sekolah ke Prancis! Kita akan ke Sorbonne! Apa pun pengorbanannya! Apapun yang akan terjadi!"

Arai berteriak. Suaranya lantang memenuhi lapangan luas sekolah kami, menerobos ruang-ruang gelap dalam kepalaku" (Hirata:143)

\subsection{Pesan Positif dari Konflik Batin Tokoh Utama}

Pengarang dalam menyampaikan pesan positif dalam cerita dapat melakukan bermacam-macam cara. Salah satunya dengan pergolakan batin atau konflik batin tokoh utamanya. Konflik batin itu dijadikan sebagai media penyampaian pesan positif tanpa menimbulkan kesan menggurui. Beberapa konflik batin yang menimpa diri Haikal dalam cerita mengandung beberapa pesan positif yang tersirat. Secara garis besar konflik batin yang menimpa Haikal dalam cerita dapat dibagi menjadi dua, yaitu: 1) konflik batin karena ingin melihat film porno; dan 2) konflik batin yang timbul akibat diterpa sikap pesimis.

\subsubsection{Pesan Positif dari Adanya Konflik Batin Karena Ingin Melihat Film Porno}

Konflik batin ini mengandung beberapa pesan positif. Pesan positif tersebut dapat dijabarkan sebagai berikut.

Pertama, menjaga akhlak yang baik itu ternyata tidaklah mudah. Haikal adalah anak yang baik dan berprestasi di sekolahnya. Selain itu, Haikal juga merupakan anak yang telah dididik ilmu agama sejak dini melalui pengajian di kampungnya dan di sekolah kemuhammadiyahannya. Akan tetapi, ketika mendapat godaan syahwat melalui sebuah pertunjukkan film yang mengumbar aurat, Haikal tidak mampu untuk menolaknya. Dia berusaha dengan berbagai cara untuk dapat menonton film tersebut. Bahkan akhirnya, Haikal berhasil menonton film yang mengumbar aurat yang seharus tidak boleh dia tonton. Kedua, kemaksiatan yang diperbolehkan bahkan difasilitasi tentu akan menimbulkan banyak korban. Haikal adalah seorang anak pelajar yang baik bahkan sudah dibekali oleh ilmu agama sejak dini. Akan tetapi, adanya bioskop yang diperbolehkan memutar film berbau pornografi telah menyeretnya ke dalam dosa akhlak. Oleh sebab itu, tindakan untuk menjaga anak didik dari serbuan pornografi dan pornoaksi merupakan kewajiban yang harus dilakukan oleh pihak-pihak terkait. Pada saat kemaksiatan diperbolehkan bahkan difasilitasi maka pada saat itu juga kerusakan akhlak generasi muda sangat mungkin untuk terjadi. Hal ini membuktikan bahwa kesalehan individu saja terkadang belumlah cukup. Kesalehan individu harus diiringi juga dengan kesalehan sosial. Pada titik inilah negara mempunyai peran aktif untuk membentengi dan menjaga akhlak generasi muda dari serbuan pornografi dan pornoaksi.

\subsubsection{Pesan Positif dari Adanya Konflik Batin yang Timbul Akibat Diterpa Sikap Pesimis}

Konflik batin ini juga mengandung beberapa pesan positif. Pesan positif tersebut dapat dijabarkan sebagai berikut.

Pertama, timbulnya pemahaman bahwa sikap pesimis bagi sebuah pejuang adalah sebuah sikap yang sangat buruk. Hal itu disebabkan sikap pesimis membuat seorang pejuang akan kalah sebelum bertempur. Dia akan beranggapan pasti akan mengalami kekalahan atau kegagalan sebelum 
menempuh langkah nyata untuk menjalani sesuatu yang diperjuangkannya. Hal ini merupakan bentuk lain dari sebuah pengkhianatan terhadap sebuah cita-cita.

Kedua, konflik batin yang menimpa Haikal ini sesungguhnya merefleksikan sebuah ajaran Islam yang menyatakaan bahwa: Allah Swt tidak akan mengubah nasib suatu kaum sebelum mereka mengubah diri mereka sendiri. Untuk mengubah diri sesungguhnya meliputi aspek psikologis juga. Mental menerima keadaan apa adanya, sikap pesimis, dan malas merupakan sesuatu hal yang harus di ubah bagi seseorang yang ingin mengubah dirinya untuk menjadi lebih baik. Hal itu disebabkan mengubah nasib tentu bukanlah sebuah perkara yang mudah. Diperlukan keseriusan, kesungguhan, tekad baja, dan semangat pantang menyerah dalam menggampai sesuatu yang dicita-citakannya. Hal yang lebih khusus lagi adalah kesiapan psikologis dalam menempuh setiap rintangan, halangan, dan kendala tersebut.

\section{Simpulan}

Novel Sang Pemimpi karya Andrea Hirata adalah sebuah novel yang sangat inspiratif bagi para pembacanya. Hal itu disebabkan banyak muatan positif yang ingin disampaikan pengarang melalui konflik batin yang menimpa tokoh utamanya dalam mengejar cita-cita.

Konflik batin dalam diri Haikal yang timbul karena ingin melihat film porno atau tidak sesungguhnya merupakan sebuah pertarungan antara mengikuti bisikan kebaikan atau keburukan. Walaupun akhirnya Haikal lebih condong mengikuti bisikan buruk yang akhirnya membuat dirinya memilih untuk menonton film tersebut. Haikal adalah anak seorang buruh timah miskin di pulau Belitong yang memiliki cita-cita ingin kuliah sampai di Sorbonne, Prancis.
Hal itu menurut pikiran normal adalah sesuatu yang sangat muskil untuk terjadi. Realitas hidup yang penuh dengan kegagalan yang menimpa temantemannya membuat Haikal menjadi pesimis bahwa cita-citanya akan tercapai. Pada titik inilah timbul konflik batin dalam diri Haikal antara keberhasilan menggapai cita-cita atau tetap terpuruk dalam lingkaran kemiskinan keluarganya.

Pesan positif yang ingin disampaikan pengarang melalui konflik batin yang dialami oleh Haikal ini mmempunyai beberapa bentuk. Pertama, konflik batin yang menyangkut moral yang menimpa Haikal merupakan pencerminan dari sebuah pemahaman yang menyatakan bahwa berperang melawan nafsu diri sendiri memang lebih sulit dibandingkan berperang dengan orang lain. Selain itu, konflik batin itu juga menandakan bahwa seorang manusia tidak cukup hanya dengan kesalehan induvidu saja, diperlukan kesalehan sosial agar kesalehan individu itu tetap terjaga.

Pesan positif dari adanya konflik batin akibat rasa pesimis tersebut terselesaikan dengan sebuah pemahaman yang sangat dalam tentang makna sebuah perjuangan yang menyatakan bahwa sesungguhnya sikap pesimis adalah sebuah pemikiran yang mendahului nasib. Orang yang memiliki pemikiran pesimis sesungguhnya adalah orang yang sudah memvonis dirinya sendiri pasti akan menemui kegagalan dalam menggapai cita-citanya. Padahal, masa depan adalah milik Tuhan dan tidak ada seorang pun yang mengetahuinya. Boleh jadi orang yang berjuang untuk mengubah hidupnya untuk menjadi lebih baik akan menemui keberhasilan dalam perjuangannya. Oleh sebab itu, janganlah pernah berhenti untuk berjuang. 


\section{Daftar Pustaka}

Aminuddin. 1990. Kajian Tekstual dalam Psikologi Sastra. Sekitar Masalah Sastra. Beberapa Prinsip dan Model Pengembangannya. Malang: Yayasan Asah Asih Asuh Malang. - 2004. Pengantar Apresiasi Karya Sastra. Malang: Sinar Baru Algesindo.

Endraswara, Suwardi. 2013. Metode Penelitian Psikologi Sastra: Teori, Langkah, dan Penerapannya. Yogyakarta: MedPress.

Hirata, Andrea. 2010. Sang Pemimpi Sebuah Novel. Yogyakarta: Penerbit Bentang

Indrawati. 2014. Konflik Batin Tokoh Richard dalam Buku a Teenager's Journey Karya Richard B. Pelzer: Suatu Tinjauan Psikologi Sastra. Jurnal Undas 10(2): 22-34.

Jahdiah. 2013. Aspek Psikologi Tokoh Utama dalam Novel Cinta Penuh Air Mata Karya Andrei Aksana. (ed) Bunga Rampai Hasil Penelitian Kesastraan (hlm.143162). Banjarbaru: Balai Bahasa Kalimantan Selatan.

Nurgiyantoro, Burhan. 2010. Teori Pengkajian Fiksi. Yogyakarta: Gajah Mada Univversity Press

Ratna, Nyoman Kutha. 2011. Teori, Metode, dan Teknik Penelitian Sastra. Yogyakarta: Pustaka Pelajar.

Semi, Atar. 2012. Metode Penelitian Sastra. Bandung. Angkasa.

Sudjiman, Panuti. 1988. Memahami Cerita Rekaan. Jakarta: Pustaka Jaya.

Tim Penyusun. 2016. Kamus Besar Bahasa Indonesia Edisi V. Jakarta: Balai Pustaka. 